\title{
Patroni ulic i placów w miasteczku akademickim Uniwersytetu Warmińsko-Mazurskiego w Kortowie
}

\begin{abstract}
Abstrakt. Names of streets and squares on the campus of the University of Warmia and Masuria in Kortowo

This article revolves around the memory of a site, i.e. the past captured in sources, reported memories of witnesses of events and symbols. The examples of such places of memory examined here are the streets and squares on the UWM Kortowo campus. They consist of references to the past which has significance for contemporary times. The article consists of an introduction and two chapters. The introduction presents the rich history of Kortowo, spanning several centuries from the Old Prussian settlements to the establishment of the University of Warmia and Masuria in Olsztyn. Chapter 1 is dedicated to the history of the streets and squares on the Kortowo campus from the time when, to make the academic community's life easier, the university authorities gave names to the streets on the campus, following the specific faculties'suggestions. The streets were named after M. Oczapowski (an agronomist, theorist of agriculture, pioneer of agricultural experimentation), R. Prawocheński (an expert in animal husbandry), J. Licznerski (a pioneer of modern dairy science), K. Obitz (Doctor of veterinary medicine, a journalist, a social activist in Masuria), J. Hevelius (an astronomer from Gdansk), B. Dybowski (a biologist and traveller), C. Kanafojski (Professor of automation in agriculture). Chapter 2 presents short biographies of three of the seven street patrons: B. Dybowski, K. Obitz and R. Prawocheński, who are the most characteristic and multi-dimensional figures. The names of the streets reflect the memory of the scientific, social and personal achievements of these individuals, at the same time justifying their selection as patrons.
\end{abstract}

Keywords: history, memory of a site, university campus in Kortowo, UWM archives, patrons of streets and squares 


\section{Wstęp}

Kortowo jest osiedlem Olsztyna, miejscem funkcjonowania Uniwersytetu Warmińsko-Mazurskiego. Większość nauczycieli akademickich i studentów kojarzy Kortowo z najpiękniejszym kampusem akademickim w Polsce, ale nie łączy go z bogatą historią ${ }^{1}$. Pierwsze ślady człowieka datować można na okres od 7800 do 1600 r. p.n.e. na podstawie znalezionego toporka z rogu łosia. Nazwa Kortowo, pochodząca od staropruskiego słowa carto, tzn. gaj, lasek, pojawiła się w przywileju lokacyjnym Olsztyna z 1353 r. Nad jeziorem Kortowskim powstawały folwarki, które zajmowały się hodowlą ryb, uprawą zbóż, a z czasem przekształcano je w majątki ziemskie. W dniu 1 października $1886 \mathrm{r}$. otwarto Prowincjonalny Zakład Leczniczo-Opiekuńczy dla Psychicznie Chorych z pawilonami dla chorych, domami dla dyrektora i pracowników, z kostnicą, lodownią, basenem, kręgielnią itd. Kortowo miało odrębną sieć wodociągowo-kanalizacyjną. ${ }^{2}$ Chorych leczono przez pracę w parku, ogrodzie, na polu, przy hodowli zwierząt. Jedną z prawdopodobnych tajemnic szpitala była akcja uśmiercania ludzi o kryptonimie T-4 ${ }^{3}$. W Kortowie, w nocy z 21-22 stycznia 1945 r. żołnierze sowieccy spalili szpital, wymordowali personel i chorych. Po wojnie, ludzie straszyli tym miejscem swoje niegrzeczne dzieci.

W 1950 r. w Kortowie została powołana do życia Wyższa Szkoła Rolnicza, przekształcona w Akademię Rolniczo-Techniczną, na bazie której w 1999 r. utworzono Uniwersytet Warmińsko-Mazurski. To dziedzictwo kultury niematerialnej i materialnej warto badać i upowszechniać, aby ocalić od zapomnienia. Moim zamierzeniem jest przedstawienie miejsc, jakimi są ulice i place Kortowa z ich wybitnymi patronami, których działalność naukowa, niepodległościowa, organizacyjna, praktyczna zasługuje na poznanie i refleksję. Tak tworzą się miejsca pamięci Kortowa ${ }^{4}$.

\section{Historia ulic i placów Kortowa}

Do 1989 r. ulice i place w Kortowie nie były nazwane. Identyfikacja określonych obiektów związana była z numeracją bloków (np. Archiwum ART można było odnaleźć pod adresem: Olsztyn, Kortowo 19). Zajmujące znaczny obszar i stale rozbudowujące się Kortowo, stanęło przed koniecznością utworzenia i nadania nazw ulicom. Starania o poprawienie funkcjonowania środowiska akademickiego podjął Rektor Akademii Rolniczo-Technicznej w Olsztynie, prof. dr hab. Włodzimierz Baran. Na mocy decyzji nr 5, z dnia 28 kwietnia 1986 r. powstała komisja ds. rozstrzygnięcia konkursu na nadanie nazw ulic

${ }^{1}$ Mikrohistoria Kortowa. Konteksty - Refleksje - Narracje, red. J.M. Garbula, Olsztyn 2014.

2 S. Achremczyk, Kortowo - od folwarku do uniwersyteckiego miasteczka, w: Mikrohistoria Kortowa..., op. cit., s. 59-67.

3 J. Chłosta, Trzy osobliwe tajemnice dawnego Kortowa, w: Mikrohistoria Kortowa..., op. cit., s. 82.

4 A. Szpociński, Nauk Nośniki pamięci, miejsca pamięci, „Sensus Historiae” 2014, vol. XVII, s. 17-25. 
w Kortowie 5 . Jej przewodniczącą została prof. dr hab. Zofia Różańska, zastępcą przewodniczącej, mgr inż. Henryk Zięciak, zaś członkami: doc. dr hab. Kazimierz Sikorski, dr Zbigniew Wróbel, mgr inż. Jerzy Kozdroń. Komisja wybrała następujące nazwy ulic: Rektorska, Akademicka, Senacka, Żaków, Techniczna, Rolnicza, Starodworska oraz dwóch placów: Cieszyński i Łódzki. Autorzy pomysłów: lek. wet. Mirosław Obijalski, dr wet. Edward Trybał, dr Jan Siemionek, dr Jowita Solarska, zostali nagrodzeni ${ }^{6}$.

Należy przypuszczać, że powyższe nazwy ulic, nie zyskały aprobaty środowiska akademickiego, czego wyrazem były pisma skierowane do Rektora, prof. dr. hab. Włodzimierza Barana oraz dyrektora administracyjnego, mgr. Edmunda Nazdrowicza, od przedstawicieli Wydziału Rolniczego ${ }^{7}$, Zootechniki ${ }^{8}$, Technologii Żywności ${ }^{9}$, Weterynarii ${ }^{10}$, Geodezji i Urządzeń Rolniczych, Ochrony Wód i Rybactwa Śródlądowego ${ }^{11}$, Mechanicznego $^{12}$ z propozycją następujących nazw ulic: M. Oczapowskiego (agronoma, teoretyka rolnictwa, pioniera doświadczalnictwa rolniczego), R. Prawocheńskiego (zootechnika), J. Licznerskiego (pioniera nowoczesnego mleczarstwa), K. Obitza (dr medycyny weterynaryjnej, dziennikarza, działacza mazurskiego), J. Heweliusza (gdańskiego astronoma), B. Dybowskiego (przyrodnika i podróżnika), Cz. Kanafojskiego (profesora mechanizacji rolnictwa), a także Rektorskiej, Senatorskiej, Żaków, prof. Bolesława Świętochowskiego.

5 Archiwum i Muzeum UWM, Biuro Rektora ART w Olsztynie, Nadawanie nazw ulicom w Kortowie, sygn. 2240/35, Decyzja nr 5 w sprawie powołania Komisji ds. rozstrzygnięcia konkursu na nadanie nazw ulic w Kortowie, 28.04.1986.

${ }^{6}$ AM UWM, Biuro Rektora ART w Olsztynie, Nadawanie nazw ulicom w Kortowie, sygn. 2240/35, Protokół z posiedzenia komisji ds. rozstrzygnięcia o nadanie nazw ulic w Kortowie, 6 czerwca 1986 r.

7 AM UWM, Biuro Rektora ART w Olsztynie. Nadawanie nazw ulicom w Kortowie, sygn. 2240/35. Pismo Katedry Ogólnej Uprawy Roślin ART. w Olsztynie do Rektora Włodzimierza Barana w sprawie nazwy jednej z głównych arterii w Kortowie, 1987.

${ }^{8}$ AM UWM, Biuro Rektora ART w Olsztynie. Nadawanie nazw ulicom w Kortowie, sygn. 2240/35. Pismo Wydziału Zootechniki Ochrony do dyrektora Administracyjnego ART mgr. Edmunda Nazdrowicza, W sprawie nazwania zaznaczonej na planie ulicy im. Romana Prawocheńskiego, 11.11.1987.

9 AM UWM, Biuro Rektora ART w Olsztynie. Nadawanie nazw ulicom w Kortowie, sygn. 2240/35. Pismo od Dziekana Wydziału Technologii Żywności prof. dr. hab. Stefana Smoczyńskiego do dyrektora Administracyjnego ART mgr. Edmunda Nazdrowicza, w sprawie nazwania ulicy, od bloku 23/24 do bloku 11/37, im. Jana Licznerskiego, 23.11.1987.

${ }^{10}$ AM UWM, Biuro Rektora ART w Olsztynie. Nadawanie nazw ulicom w Kortowie, sygn. 2240/35. Pismo od Dziekan prof. dr. hab. Remigiusz Fiiko, do dyrektora Administracyjnego ART mgr. Edmunda Nazdrowicza, w sprawie nazwania ulicy biegnącej od trasy autobusu linii nr 3 do CPN im. dr. Kurta Obitza, 21.07.1987.

${ }^{11}$ AM UWM, Biuro Rektora ART w Olsztynie. Nadawanie nazw ulicom w Kortowie, sygn. 2240/35, Pismo do dyrektora Administracyjnego ART mgr. Edmunda Nazdrowicza, do dziekana Wydziału Ochrony Wód i Rybactwa Śródlądowego, doc. dr. hab. Konstanty Lossow w sprawie nazwania ulicy im. Benedykta Dybowskiego, 20.11.1987.

12 AM UWM, Biuro Rektora ART w Olsztynie. Nadawanie nazw ulicom w Kortowie, sygn. 2240/35. Pismo dziekana Wydziału Mechanicznego, doc. dr. hab. Kazimierza Wierzbickigo do dyrektora Administracyjnego ART mgr. Edmunda Nazdrowicza, z propozycją nazwania wyznaczonej ulicy im. prof. zw. dr. hab. inż. Czesława Kanafojskiego, a także z propozycją nazwania jednej z ulic przy Wydziale Mechanicznym ulicą Techniczną, a drugą ulicą Rolniczą, 11.10.1987. 
Tę ostatnią propozycję zgłosili Witold Niewiadomski i Michał Skrodzki z Katedry Ogólnej Uprawy Roli i Roślin Wydziału Rolniczego ART z następującym uzasadnieniem: W roku 1964 nasza uczelnia nadała mu godność Doktora Honoris Causa. Nadanie ulicy jego imienia bytoby wyrazem hołdu i pamięci wielkiemu Polakowi, twórcy nauk rolniczych w Polsce ${ }^{13}$.

Na podstawie powyższych sugestii, następca Rektora ART, profesora Włodzimierza Barana, Rektor, prof. dr hab. Jerzy Strzeżek, sformułował wniosek, z dnia 15.03.1988, do Przewodniczącego Miejskiej Rady Narodowej w Olsztynie, ob. inż. Stanisława Grzegorzaka, o nadanie ulicom Kortowa nazw wybitnych uczonych związanych z rodowodem ART, tzn.: ul. im. Michała Oczapowskiego, ul. im. Jana Licznerskiego, ul. im. J. Heweliusza, ul. im. Kurta Obitza, ul. im. Romana Prawocheńskiego, ul. im. Cz. Kanafojskiego, ul. im. Benedykta Dybowskiego oraz nazw dwóch głównych placów: Plac Cieszyński, Skwer Łódzki ${ }^{14}$. Do wniosku dołączone zostały: plan Kortowa z propozycją patronów ulic, a także pozytywna opinia Komitetu Osiedlowego Samorządu Mieszkańców „Kortowa”. Procedura związana $\mathrm{z}$ nadaniem ulicom nazw wymagała zaopiniowania wniosku przez społeczność lokalną, w tym przypadku Radę Osiedla „Kortowo"15. Z pismem w tej sprawie zwróciła się do przewodniczącego Rady, obywatela dr. Zbigniewa Wróbla, sekretarz uczelni Biura Rektora, mgr inż. Ewa Burska-Kazimierska. W odpowiedzi Samorząd Mieszkańców poparł propozycję władz Uczelni w sprawie nadania nazw ulicom Kortowa ${ }^{16}$.

Wniosek o nadanie nazw ulicom Kortowa, rozpatrywano na trzeciej zwyczajnej Sesji Miejskiej Rady Narodowej w Olsztynie, w dniu 29 grudnia 1988 r., w następującym składzie: z-ca Przewodniczącego Wojewódzkiej Rady Narodowej, ob. Elżbieta Olbromska; I Sekretarz KM PZPR, Stefan Strumiłło; Prezes Miejskiego Komitetu ZSL, Kazimierz Filuś; Przewodniczący Miejskiego Komitetu SD, Janusz Piechocki; Przedstawiciel „PAX” Franciszek Tryniszewski; Przewodniczący Rady Miejskiej PRON, Józef Boczek; Prezydent Miasta Olsztyna, Marek Różycki; Wiceprezydent Miasta, Marian Zyska; zaproszeni goście; przewodniczący Komitetów Osiedlowych Sam. Mieszk.; kierownicy wydziałów Urzędu Miejskiego; członkowie komisji spoza Rady. Wniosek Uczelni zaopiniowany został pozytywnie przez Zespół Doradczy d.s. nazewnictwa ulic przy Prezyden-

\footnotetext{
${ }^{13}$ AM UWM, Biuro Rektora ART. w Olsztynie. Nadawanie nazw ulicom w Kortowie, sygn. 2240/35, Pismo Witolda Niewiadomskiego i Michała Skrodzkiego z Katedry Ogólnej Uprawy Roli i Roślin Wydziału Rolniczego ART w sprawie nazwania jednej z ulic w Kortowie, im. prof. Bolesława Świętochowskiego.

${ }^{14}$ AM UWM, Biuro Rektora ART. w Olsztynie. Nadawanie nazw ulicom w Kortowie, sygn. 2240/35. Wniosek do Przewodniczącego Miejskiej Rady Narodowej w Olsztynie, ob. inż. Stanisława Grzegorzaka o nadanie nazw ulicom Kortowa. 15.03.1988.

${ }^{15}$ AM UWM, Biuro Rektora ART. w Olsztynie. Korespondencja wewnętrzna i zewnętrzna 1987-1988. Pismo sekretarza uczelni z Biura Rektora, mgr inż. Ewy Burskiej-Kazimierskiej do przewodniczącego Rady Osiedla „Kortowo”, obywatela dr. Zbigniewa Wróbla w sprawie zaopiniowania wniosku, 08.12.1987.

${ }^{16}$ AM UWM, Biuro Rektora ART. w Olsztynie. Nadawanie nazw ulicom w Kortowie, sygn. 2240/35. Pismo od przewodniczącego Rady Osiedla obywatela dr. Zbigniewa Wróbla do Dyrektora Administracyjnego ART. w Olsztynie, 09.03.1988.
} 
cie m. Olsztyna ${ }^{17}$. W uzasadnieniu podano, że nazwy ulic konsultowano uprzednio ze środowiskiem akademickim i pochodzą one od nazwisk uczonych, którzy w wybitny sposób zapisali się w historii nauki polskiej w dziedzinie weterynarii, rolnictwa, zootechniki, zoologii i mleczarstwa. Nazwy placów wywodzą się z rodowodu Uczelni, która powstała w wyniku przeniesienia szkół gospodarstwa wiejskiego z Cieszyna i Łodzi ${ }^{18}$.

Po spełnieniu wszystkich powyższych formalności oraz na podstawie art. 18 ust. 2 Ustawy z dnia 20 lipca 1983 roku o systemie rad narodowych i samorządu terytorialnego (Dz.U. nr 41, poz. 185 z późn. zmian.), Miejska Rada Narodowa w Olsztynie, podjęła przy trzech wstrzymujących się głosach, następują uchwałę:

Nadaje się następujące nazwy ulic i placów w Osiedlu Kortowo: ulica prof. Michała Oczapowskiego, ulica prof. Romana Prawocheńskiego, ulica prof. Jana Licznerskiego, ulica prof. Czestawa Kanafojskiego, ulica prof. Benedykta Dybowskiego, ulica Jana Heweliusza, ulica dr. Kurta Obitza, Plac Cieszyński, Plac Łódzki. Uchwate wykona Prezydent Miasta Olsztyna. Uchwała wchodzi w życie po uptywie 14 dni od daty ogłoszenia w Dzienniku Urzędowym Województwa Olsztyńskiego. Przewodniczacy Miejskiej Rady Narodowej inż. Stanisław Grzego$r z a k^{19}$.

Informacja ta dotarła z Sekretariatu Rektora, dn. 23 marca 1989 r., do kierowników jednostek organizacyjnych $\mathrm{w} / \mathrm{m}^{20}$.

Nadawanie nazw ulicom łączy się ze zmianą numeracji budynków przy nich zlokalizowanych. W piśmie z Urzędu Miasta w Olsztynie, Wydziału Geodezji, Gospodarki Gruntami, Rolnictwa i Leśnictwa, podpisanym przez st. inspektora miejskiego, Wojciecha Michulskiego do Akademii Rolniczo-Technicznej w Olsztynie, z dn. 21 czerwca 1989 r., czytamy: Zawiadamiam, że zostaty nadane numery porzadkowe (milicyjne) na budynki w oś. Kortowo zlokalizowane przy następujacych ulicach ... ${ }^{21}$ i tu następuje lista ulic oraz stare numery 63 bloków i nowe numery porządkowe. Na przykład przy najkrótszej ulicy im. prof. Jana Licznerskiego, trzem znajdującym się tam blokom, tzn. 20a, 20b (przedszkole), 20b (Instytut Matematyki) nadano następujące numery porządkowe 6, 2, 4. W wyżej wymienionym piśmie, st. insp. Wojciech Michulski przypomniał o obowiązku umieszczenia $w$ miejscu widocznym na budynku tabliczki z wyraźnym numerem po-

${ }^{17}$ Archiwum Państwowe w Olsztynie, Miejska Rada Narodowa, sygn. 1278, Protokół NIII/88, s. 1. Opinia Komisji Kultury, Kultury Fizycznej i Turystyki MRN dla Komisji Oświaty i Wychowania MRN dotycząca projektu uchwały w sprawie nazewnictwa ulic w mieście.

${ }_{18}$ APO, Miejska Rada Narodowa, sygn. 1278, Protokół NIII/88, Uzasadnienie do uchwały Miejskiej Rady Narodowej w Olsztynie w sprawie nadania nazw ulicom i placom na terenie miasta Olsztyna.

${ }_{19}$ APO, Miejska Rada Narodowa, sygn. 1278, W sprawie nadania nazw ulicom i placom na terenie miasta Olsztyna. Załącznik nr 15 oraz Załącznik nr 17.

${ }^{20}$ AM UWM, Biuro Rektora ART w Olsztynie, Nadawanie nazw ulicom w Kortowie, sygn. 2240/35, Pismo z-cy dyrektora administracyjnego d/s technicznych, inż. Stanisława Kurjana do kierowników jednostek Organizacyjnych w/m. 23.03.1989.

${ }^{21}$ Nr: GR. VII. 84-9/89. APO, Miejska Rada Narodowa, sygn.1278, Nadawanie nazw ulicom w Kortowie, sygn. 2240/35. Nadawanie numerów administracyjnych (milicyjnych) budynkom, 21 czerwca 1989. 
rzadkowym budynku oraz nazwa ulicy. Tabliczki z numerami porzadkowymi powinny być utrzymane stale $w$ należytym stanie $i$ od zmroku do świtu oświetlone ${ }^{22}$. Pismo to trafiło także do Wydziału Społeczno-Administracyjnego, Oddziału Spraw Lokalowych, WUS-u Oddziału Statystyki Miejskiej, Rejonowego Urzędu Spraw Wewnętrznych, W.O.D.G-K. w Olsztynie, O.P.G-K. w Olsztynie.

Nadanie nazw ulicom i placom w miasteczku akademickim Kortowo okazało się procesem pracochłonnym i złożonym, który przebiegał od planowania, konkursów, dyskusji i konsultacji (akademickich, lokalnych), działań administracyjnych, aż do decyzji na najwyższym szczeblu władz uczelni i miasta. To zaangażowanie wielu osób doprowadziło do wielu ułatwień dotyczących funkcjonowania społeczności akademickiej i wtedy, i teraz. Po raz kolejny przeszłość „pokazała” jak ważna jest dla teraźniejszości.

\section{Patroni ulic kortowskiego kampusu}

Spośród siedmiu patronów kortowskich ulic wybranych przez społeczność kortowską i zaakceptowanych przez władze Olsztyna, przedstawiam sylwetki sześciu naukowców, których poznanie wymagało ode mnie wielotygodniowych kwerend archiwalnych i bibliotecznych na terenie całego kraju. Nie charakteryzuję życia i działalności wielkiego astronoma Jana Heweliusza $\mathrm{z}$ racji dostępności materiałów na jego temat również na stronach internetowych.

\section{Benedykt Dybowski}

Patronem jednej z ulic akademickiego miasteczka jest Benedykt Dybowski, wielki zoolog, lekarz, antropolog, działacz niepodległościowy, zesłaniec syberyjski. Żył w latach 1833-1930, w większości wpisanych w okres zaborów i wojny, mających wpływ na jego życie zawodowe, społeczne i osobiste.

Urodził się na Białorusi w wielodzietnej rodzinie szlacheckiej herbu Nałęcz, dla której największą wartością była głęboka miłość do Ojczyzny. Pasja przyrodnicza rosła wraz z nim, stając się jego zawodem, codziennością. Studia przyrodnicze realizował równolegle ze studiami medycznymi, początkowo w Uniwersytecie Dorpackim, później we Wrocławiu i Berlinie. W 1860 r. w Berlinie uzyskał stopień doktora na wydziale lekarskim, który nostryfikował w Dorpacie w 1862 r. Pracę naukową rozpoczął w 1862 r. w Szkole Głównej w Warszawie, na stanowisku profesora adiunkta w katedrze zoologii.

Oprócz pracy zawodowej prowadził działalność społeczną i patriotyczną. Był współzałożycielem kółka „Braci mlecznych”, skupiającego pierwszych abstynentów w Polsce walczących z alkoholizmem rodaków. Współorganizował Towarzystwo Patriotyczne, mające na celu odrodzenie społeczeństwa polskiego, w dążności do wyzwolenia ojczy-

\footnotetext{
${ }^{22}$ Ibidem.
} 
$z^{2 n}{ }^{23}$. Podobne cele przyświecały jego działaniom w Organizacji Narodowej Litwy, polegające m.in. na zorganizowaniu manifestacji połączonej z odśpiewaniem pieśni Boże coś Polskę w dzień św. Stanisława, w katedrze wileńskiej, zakończonej aresztowaniem.

B. Dybowski współpracował ściśle z Rządem Narodowym. Mianowany Komisarzem na Kresy Wschodnie, odbywał liczne podróże agitacyjne, m.in. do Wilna, Żytomierza. Wydany podczas przesłuchań, przez współtowarzyszy, został ponownie aresztowany w lutym 1864 r. i skazany początkowo na karę śmierci, zamienioną dzięki wpływowym przyjaciołom, na 12 lat ciężkich robót na Syberii. Osłabiony fizycznie i psychicznie stracił sens życia. Wyrwały go z marazmu przypomniane przez kolegów podczas pożegnania na dworcu słowa: siła woli przezwycięży wszystko oraz paczka od nich zawierająca m.in. mikroskop ${ }^{24}$. Celem, jaki sobie postawił w tej trudnej rzeczywistości, było zbadanie mało poznanej przyrody Syberii. 10 sierpnia 1864 r., wraz z 50 zesłańcami, wyruszył w 8000 km drogę, która wiodła z Warszawy przez Petersburg, Moskwę, Niżny Nowogród, Tobolsk, Irkuck, Czytę, Darasuń. Poruszali się różnymi środkami transportu, począwszy od kolei żelaznej przez kibitkę, sanie aż do pieszej wędrówki, do wiosny $1865 \mathrm{r}$.

Na zesłaniu, pozostawał pod strażą, ale uzyskał pozwolenie na pracę, którą najczęściej wykonywał w lesie, badając miejscową przyrodę.

Całe szczęście, że roboty przymusowe byly tu lizejsze niż w innych miejscach, gdzie byty kopalnie, jak np. w Nerczyńsku. Byly one tutaj dwojakiego rodzaju: jedne o charakterze publicznym, jak naprawa dróg, oczyszczanie $i$ wzmacnianie brzegów rzeki, rąbanie $i$ zwożenie drzewa $z$ lasu oraz jego obróbka na budowę wielkich todzi, zwanych barżami; $i$ inne, związane z gospodarka samej partji zesłańców, a więc wożenie wody z rzeki, czyszczenie podwórza i kazamatów, palenie pod kotłami i t. p. Każdemu wyznaczano przydziat roboty, jaka miat wykonać danego dnia, i karano zazwyczaj zamknięciem na noc bez jadła w tak zwanej ,katałaszce“, jeżeli kto nie spetnit w calości zadanego przydziatu. [...] Dybowski pracowat narówni z innymi, ale najchętniej podejmowat się zajęć w lesie - rąbania i zwózki drzewa, bo wówczas prawie zawsze mógł urwać trochę czasu na robienie zbiorów i badanie przyrody miejscowej ${ }^{25}$.

Z czasem, dzięki zaangażowaniu wielu osób i nieposzlakowanej opinii, uzyskał zgodę na przesiedlenie i badanie fauny Bajkału, po jakucku „Świętego morza”. Początkowo osiedlili się we wsi Kułtuk, gdzie w latach 1869-1877, stworzył stacjonarną szkołę limnologiczną, która skupiała 19 współpracowników będących zesłańcami. Wśród nich wymienia się 3 profesjonalnych przyrodników (Benedykt Dybowski - zoolog i limnolog, Aleksander Czekanowski - geolog i paleontolog, Jan Czerski - anatom i geolog), 3 amatorów przyrodoznawstwa (Wiktor Godlewski - limnolog, Józef Łagowski - botanik,

${ }^{23}$ L. Bykowski, Dybowski Benedykt, w: W. Konopczyński (red.), Polski słownik biograficzny, red. W. Konopczyński, t. VI, Polska Akademia Umiejętności, Kraków 1948, s. 36.

${ }^{24}$ B. Dyakowski, Badacz Dalekiej Pótnocy. Benedykt Dybowski, Nakład Księgarni św. Wojciecha, Poznań Warszawa - Wilno - Lublin 1931, s. 13.

25 Ibidem, s. 22-23. 
Józef Kalinowski - nauczyciel) oraz 13 innych badaczy, którzy tutaj wykształcili się na znawców różnych grup zwierząt lub zagadnień z dziedziny zoologii ${ }^{26}$.

Wraz z W. Godlewskim, własnym sumptem, prowadzili badania w wyrąbanych przez siebie 200 przeręblach, zapuszczając przyrządy łowcze, na głębokość od 400-1240 metrów ${ }^{27}$. Uporządkowane, opisane i oznaczone zbiory wysyłali Towarzystwu Geograficznemu w Irkucku. Jego odkrycie, iż fauna jeziora słodkowodnego, składa się ze zwierząt o charakterze morskim (np. foka) i słodkowodnym (np. większość gąbek), podobnym do charakteru odpowiednich gatunków z innych wód słodkich, zapewniły mu miejsce w światowym panteonie naukowców oraz złoty medal od Towarzystwa Geograficznego. Wielką sławę przyniosło mu także badanie nad rybą gołomianką, którą nazywał „chlubą Bajkału i swoją". Odkrył, że jest ona żyworodna i po wydaniu potomstwa martwa wypływa na powierzchnię. Te wszystkie zasługi pomogły mu w uzyskaniu ostatecznej amnestii i powrocie do ojczyzny w $1877 \mathrm{r}$.

Na czołowych uniwersytetach nie było wolnych etatów, stąd decyzja B. Dybowskiego o przyjęciu pracy na Kamczatce, w charakterze lekarza obwodowego. Na zarzuty przyjaciół, mających mu za złe pracę dla ciemiężyciela, odpowiedział krótko: „poza Ojczyzną", lecz „dla niej wyłącznie”"28. Na Kamczatce pracował i podróżował wraz z Janem Kalinowskim przez 5 lat, objechawszy ją 5 razy. Prowadził działalność humanitarną i lekarską polegającą na zwalczaniu epidemii tyfusu, trądu i ospy; zakładaniu szpitali i przytułków dla trędowatych, walczył o poprawę bytu ludności. Uczył miejscową ludność uprawiać ziemię, stosować nawozy, przesiedlał renifery, konie, króliki i kozy swojskie. Miejscowi nazywali go Dobrym Białym Bogiem ${ }^{29}$. Oprócz tego prowadził nieustającą działalność naukową, której rezultatem były wielkie kolekcje zoologiczne, antropologiczne (czaszki miejscowej ludności), a także zebrał imponujący materiał językowy o narzeczach plemion. Ofiarował muzeum zoologicznemu we Lwowie około 8000 cennych okazów, skorupiaków, mięczaków, ryb, ptaków i ssaków.

Po powrocie do kraju w 1883 r., przyjął posadę profesora zwyczajnego zoologii i autonomii porównawczej na Uniwersytecie Lwowskim i wykładał do 1906 r. Z okazji 50-lecia pracy oddały mu cześć wszystkie środowiska akademickie, zaś ludność Kamczatki przysłała mu w darze szkielet zaginionej krowy morskiej, będącej wielorybem roślinożernym o długości 8 metrów. Obecnie eksponat ten znajduje się w Muzeum Zakładu Zoologicznego Uniwersytetu Jana Kazimierza we Lwowie. W wieku 73 lat przeszedł na emeryturę, kontynuując pracę w swoim „Białym Domku” przy ul. Zaścianek we Lwowie. I wojnę światową przetrzymał w trudach i niedostatku, pracując niestrudzenie

26 J. Dziekońska-Rynko, D. Mierzwa-Szymkowiak, M. Słupek, Benedykt Dybowski (1833-1930) - lekarz, przyrodnik, społecznik, patriota. Wydarzenia upamiętniajace polskie badania na Syberii i Kamczatce, Biuletyn „PANorama” 2018, nr 4 (6), s. 14.

27 B. Dyakowski, op. cit., s. 35-37.

${ }_{28}$ B. Dybowski, O Syberyi i Kamczatce, „Drukarnia Udziałowa” (K. Wiesnera) Lindego, Lwów 1899,

29 J. Dziekońska-Rynko, D. Mierzwa-Szymkowiak, M. Słupek, op. cit., s. 14. 
do końca życia. O tym, jak bardzo kochał swoją Ojczyznę świadczy odrzucenie propozycji dopisania do jego nazwiska przydomku Bajkalski. Benedykt Dybowski nie chciał, aby jego polskie nazwisko łączone było z rosyjskim. Opublikował dziennik o pobycie na Syberii i Kamczatce, który dedykował ukochanemu bratu:

pamięci brata mego Władysława, którego zgon poprzedzit niestety wydawnictwo. Pracując z nim razem na wspólnej niwie przyrodniczej, mieliśmy jednakie upodobania, przekonania, dążenia i cele. [...] Od lat dziecięcych, aż do chwili, gdy ziemia mogilna przykryła zwłoki jego, mieliśmy, że tak rzeke, jedna duszę. Obecnie osierocony przez zgon, najserdeczniejszego przyjaciela i najukochańszego brata, znajduje pociechę $w$ rozpamiętywaniu przeszłości nam wspólnej ${ }^{30}$.

\section{Kurt Alfred Obitz}

Patronem innej z ulic Kortowa jest Kurt Alfred Obitz, działacz i bojownik o wolność Mazurów, dr medycyny weterynaryjnej, parazytolog. Jego pionierska metoda zwalczania pasożytów u zwierząt, przyczyniła się do rozwoju polskiej weterynarii. Urodził się 16 stycznia 1907 r., w Brzozowie, w powiecie węgorzewskim. Jego rodzice, Fryderyk i Ludwika z domu Bartk, byli właścicielami 300 ha gospodarstwa oraz 2 kamienic w Królewcu. Czuli się Mazurami i w tym duchu wychowywali swoje dzieci, zapewniając im solidne wykształcenie. K.A. Obitz ukończył szkołę elementarną w Brzozowie, gimnazjum w Królewcu oraz studia w Wyższej Szkole Weterynaryjnej w Berlinie. W trakcie studiów podjął działalność na rzecz Mazurów, co zaniepokoiło rektora Wyższej Szkoły Weterynaryjnej w Berlinie, prof. Schottlera, który zwrócił się, do wschodnioniemieckiej służby ojczyźnianej w Olsztynie, o opinię na jego temat ${ }^{31}$. Heimatdienst odpowiedział, iż K.A. Obitz czuje przynależność z Polską, współpracuje z kołami polskimi skupionymi wokół „Gazety Olsztyńskiej” i „Mazurskiego Przyjaciela Ludu” i zalecił jego obserwację $\mathrm{i}$ inwigilację.

Lekarzem weterynarii i jednocześnie doktorem medycyny weterynaryjnej został w 1930 r. Krótko pracował w rzeźni w Hamburgu i jeszcze krócej w Instytucie Parazytologii, Wyższej Szkoły Weterynaryjnej w Berlinie jako asystent prof. Nőllera. Powodem była wzmożona działalność w Centrali Związku Mazurów w Berlinie oraz publikowanie w miesięczniku „Cech” (1928-1933), zaczynającego się polskim mottem Gwara nasa, trzymaicie, później Wiara nasa, trzymaicie sięe $e^{32}$ W piśmie zamieścił m.in. swój wiersz pt. Młodziė̇ Mazurska! ${ }^{33}$, który zaczynał się od słów Młodzieży mazurska, do boju, Mazurska młodzieży na szańce, zaś kończył zachętą Hej naprzód! Do walki! Do boju!

${ }^{30}$ B. Dybowski, O Syberyi i Kamczatce. Podróż z Warszawy na Kamczatkę, cz. 1, Przedmowa, s. VII.

B. Dybowski, O Syberyi i Kamczatce. Podróż z Warszawy na Kamczatkę, cz. 1, Wyd. G. Gebethner i Spółka, Gebethner i Wolff, Kraków - Warszawa 1912.

31 S. Wadowski, Wspomnienia o doktorze Obitzu, „Warmia i Mazury” 1962, nr 1, s. 6.

${ }^{32}$ T. Waszkiewicz, Obitz Kurt Albert (1907-1945), w: Polski stownik biograficzny, t. XXIII, Wrocław Warszawa - Kraków 1978, s. 430.

${ }_{33}$ K. Obitz, Młodzież Mazurska!, „Cech” 1931, nr 4. 
Z wizją wolności Mazurów, nie chcieli pogodzić się berlińscy studenci. Bunt przeciwko K.A. Obitzowi, miał miejsce podczas wykładu profesora Nöllera. Oskarżony o uprawianie polskiej agitacji i zdradę ojczyzny został w 1931 r. usunięty z uczelni. W jego imieniu decyzję tę zaskarżył, bez powodzenia, radca prawny Związku Polaków w Niemczech, dr Bruno Opęchowski.

Ulegając zmasowanemu atakowi, toczonemu nie tylko na sali wykładowej, ale i w prasie, K.A. Obitz zdecydował o wyjeździe do Polski. Ministerstwo Spraw Zagranicznych pomogło mu zdobyć posadę starszego asystenta w Katedrze Zoologii i Parazytologii, na Wydziale Weterynaryjnym UW. Pracował intensywnie i w krótkim czasie przygotował 7 rozpraw naukowych. W 1935 r. został kierownikiem Działu Zwalczania Chorób Pasożytniczych, na Wydziale Weterynaryjnym, Państwowego Instytutu Naukowego Gospodarstwa Wiejskiego w Puławach.

W Puławach spotkał mnie młody, przystojny doktor, który, od poczatku okazal mi dużo życzliwości i zrozumienia. W pracy byt wymagajacy, ale sprawiedliwy i bardzo koleżeński. Wspótpraca z nim ułożyła się jak najlepiej. Łaczyła nas praca naukowa, wspólne zainteresowania. [...] Utrzymywat caly czas kontakty z działaczami mazurskimi, a poniewaz byly to kontakty nielatwe, korespondencja dochodzila do niego różnymi drogami. Pamiętam, jak na przyklad przychodzity do niego, do Instytutu listy przez Lotwe, adresowane na nazwisko dr Kellevis. Pisał też artykuty do pracy przeznaczonej za kordon. Interesowat się też żywo koncepcja Zwiqzku Battyckiego. Zbierat wszystkie materiaty, majace jakikolwiek zwiqzek ze sprawami Warmii i Mazur ${ }^{34}$.

Opublikował 18 artykułów naukowych, również współautorskich w fachowych czasopismach weterynaryjnych. W uznaniu zasług i z uwagi na znajomość języków obcych, został delegowany do Instytutu Pasteura w Algierii, do Zakładu Parazytologii Wydziału Medycznego Uniwersytetu w Paryżu, a także powołany w skład Naukowej Rady Weterynaryjnej przy Ministerstwie Rolnictwa.

Pracę naukową, życie rodzinne (żona Helena z d. Szylska) łączył z działalnością w Mazurskim Komitecie Opieki Kulturalnej i Związku Mazurów w Działdowie. M. Wańkowicz, podsumowując jego działalność nazwał go wojownikiem o odrębność i wolność wsi mazurskiej ${ }^{35}$. W 1937 r., K.A. Obitz, napisał Dzieje ludu mazurskiego ${ }^{36}$. Pracując i mieszkając w Puławach i Michałówce, utrzymywat cały czas kontakty z działaczami mazurskimi, a ponieważ byty to kontakty niełatwe, korespondencja dochodziła do niego różnymi drogami. Zbierał wszystkie materiały, mające jakikolwiek zwiazek ze sprawami Warmii i Mazur ${ }^{37}$.

Jego praca niepodległościowa wśród Mazurów, wywoływała wściekłość Niemców. Rodzina, przyjaciele i działacze ostrzegali go przed aresztowaniem. Gestapo pojawiło się

\footnotetext{
34 S. Wadowski, op. cit., s. 7.

35 M. Wańkowicz, Na tropach Smętka, Warszawa 1958.

36 K.A. Obitz, Dzieje ludu mazurskiego, Dąbrówno 2007.

37 S. Wadowski, op. cit., s. 7.
} 
po niego, 8 lutego $1940 \mathrm{r}$ w Instytucie w Puławach. Został ostrzeżony, ale nie uciekł. Wrócił do domu, do Michałówki, aby żonę i przyjaciół nie spotkały represje. Został osadzony w więzieniu i oskarżony o działanie na szkodę państwa niemieckiego (1940). W podobozie w Monachium przebywał od 1949-1942 r., a kolejne trzy lata (1942-1945) był więźniem o numerze 13377, w obozie koncentracyjnym w Dachau. Opiekował się tam królikarnią i psiarnią obozową, wykradał żywność dla więźniów, mimo że sam był chory na gruźlicę. Do rodziny (żony i córki Ewy), które przebywały w Końskich, nie wrócił, zmarł 26 sierpnia 1945 r., w wieku 38 lat, nie zobaczywszy swoich najbliższych. Na łożu śmierci, w sanatorium w Lautrach (Bawaria), opiekującej się nim zakonnicy niemieckiej wyznał: Jestem Polakiem.

\section{Roman Prawocheński}

Urodził się 11 września 1877 r. w Liwience, w guberni woroneskiej. Był synem Romana, lekarza wojskowego i ziemskiego oraz Marii z Majewskich. Naukę szkolną pobierał kolejno w progimnazjum w Ostrogożsku, w gimnazjum filologicznym w Taganrogu (matura 1896), zaś studia odbywał na wydziale matematyczno-przyrodniczym Uniwersytetu w Petersburgu. Interesował się zoologią, antropologią i rolnictwem. Studia ukończył w 1902 r. na podstawie pracy „Charakter i typ czaszek ludu białoruskiego"38. W 1904 r. ukończył również Instytut Leśny w Petersburgu. Jego kariera zawodowa rozwijała się w szybkim tempie. Zajmował się zarówno hodowlą zwierząt, jak i organizowaniem wystaw, tworzeniem spółdzielni mleczarskich i wzorcowej zarodowej obory bydła. Jako delegat Ministerstwa poznawał hodowlę zwierząt w Wielkiej Brytanii, Szwecji, Danii i Francji, zyskując kontakty międzynarodowe i własną renomę. Życie zawodowe związane $\mathrm{z}$ hodowlą łączył $\mathrm{z}$ intensywną pracą naukową. Prowadził zaawansowane badania naukowe z zakresu hodowli koni, owiec i żywienia zwierząt, które publikował w różnego rodzaju pracach i artykułach (ok. 30). Prowadził także wykłady szkoleniowe dla instruktorów owczarstwa (od 1912 r.), wykłady dla agronomów i weterynarzy (1919 r.). Rozpoczął współpracę z polskimi hodowcami, których poznał na wystawie rolniczej w Lublinie.

W 1919 r., wieku 42 lat, rozpoczął życie w Polsce wraz z żoną Heleną z Świętorzeckich i dziećmi: synem Romanem (późniejszy docent ichtiologii) i córką Ireną. Był to czas kiedy w Polsce, po ponad 120 latach niewoli, budowały się zręby państwowości polskiej, w którą włączył się R. Prawocheński, tworząc polską naukę doświadczalnictwa zootechnicznego i hodowli zwierzą ${ }^{39}$. Należał do grupy 7 wybitnych uczonych i praktyków w dziedzinie hodowli zwierząt, którzy w 1922 r. założyli Polskie Towarzystwo Zootechniczne im. Michała Oczapowskiego.

W roku 1920 podjął pracę, początkowo w Wydziale Hodowli Koni Ministerstwa Rolnictwa i Dóbr Państwowych, a następnie w Wydziale Hodowli Zwierząt Państwowego Instytutu Naukowego Gospodarstwa Wiejskiego w Puławach jako kierownik. Równole-

\footnotetext{
${ }^{38}$ Polski stownik biograficzny, red. Z. Kosiek, Kraków 1948, s. 364.

${ }^{39}$ Z. Staliński, Złota księga Akademii Rolniczej im. Hugona Kotłątaja, Kraków 2003.
} 
gle został zastępcą profesora hodowli ogólnej zwierząt w Szkole Głównej Gospodarstwa Wiejskiego w Warszawie. Zajmował się wówczas głównie zagadnieniami związanymi z hodowlą $\mathrm{koni}^{40}$. W 1925 r. został zatrudniony na Wydziale Rolniczym Uniwersytetu Jagiellońskiego jako profesor zwyczajny hodowli. Pełnił tam m.in. funkcję dziekana, prodziekana. Aż do II wojny światowej był to najbardziej owocny czas w jego działalności naukowej. Napisał dwa ważne podręczniki: Hodowla świń i Hodowla owiec, prowadził też rozległe badania międzynarodowe. Wraz z profesorem Uniwersytetu w Cambridge przeprowadził pierwszy na świecie eksperyment wykorzystania nasienia przesyłanego na duże odległości, w tym przypadku z Anglii do Polski.

R. Prawocheński dużo publikował m.in. w: „Przeglądzie Hodowlanym”, „Jeźdźcu i hodowcy”, „Medycynie Weterynaryjnej”, „Gazecie Rolniczej”. W tej ostatniej najczęściej zabierał głos w działach „Poradnik Gospodarski’, „Spostrzeżenia i głosy z praktyki”, czy sprawozdaniach z licznych wystaw rolniczych. Jedno z nich pt. Listy z Anglii ${ }^{41}$, opisywało doroczną wystawę rolniczą „Royal Show” zarówno pod względem merytorycznym (np. „W dziale koni wybijały się tak ilością, jak i jakością suffoloki i perszerony") ${ }^{42}$, jak i pod względem krajobrazów, ludzi, sposóbu podróży:

Tanie a doskonate wino reńskie sprzedawane $w$ pociagu $w$ bufetach wagonowych $i$ wagonach szklankami patentowymi, ładne urozmaicone widoki żyznej Westfalii. Tunele zamieniaja się kolejno z wiaduktami, przerzuconymi przez urocze doliny wijace się tu i ówdzie wstęga wody ${ }^{43}$.

Ten dobry okres naukowo-badawczy R. Prawocheńskiego przerwała II wojna światowa. Dnia 6 listopada 1939 r. w ramach Sonderaktion Krakau, wraz z innymi profesorami Uniwersytetu Jagiellońskiego, został aresztowany i przewieziony początkowo do więzienia na Montelupich, potem kolejno do koszar Pułku Piechoty na ul. Mazowieckiej, a następnie przez Wrocław i Berlin do obozu koncentracyjnego w Sachsenhausen, z którego w 1940 r. został uwolniony. Taki obraz tego barbarzyństwa zachował się w pamięci profesora:

Ustawiono nas znowu w szereg i przez ladny sosnowy las przeprowadzono między podwójna linia żotnierzy trzymajacych karabiny z bagnetem, zwrócone $w$ nasza stronę jak do ataku [...] W ogóle uważano widocznie Bogu ducha winnych profesów za niebezpiecznych ludzi jakiś. Właściwie straż o nas nic nie wiedziała, co też się okazało, gdy nas przyprowadzono do olbrzymiego placu otoczonego parkiem ze strzelnicami, w środku którego przed barakiem ustawiono i S[S]mani miejscowi zaczęli nas rozpytywać: „Ską, co za jedni” [...]. Po rozebraniu się do naga i zanumerowaniu każdego z nas popychano, starych i niedolężnych, $w$ sposób brutalny. Niektórzy padali idac do taźni między S[-S]manami i badającymi nasze ciało - czy wolne od wszy - więźniami [...] Po skończonej operacji przyjęcia z goleniem, myciem i przeistoczeniem

\footnotetext{
40 R. Prawocheński, W sprawie ochrony konia w Polsce, „Gazeta Rolnicza” 1935, nr 33/34, s. 1079-1080.

${ }^{41}$ R. Prawocheński, Listy z Anglii, „Gazeta Rolnicza” 1935, nr 33/34, s. 913.

42 Ibidem, s. 914.

43 R. Prawocheński, Wrażenia z IPA, „Gazeta Rolnicza” 1930, nr 27-28, s. 1102.
} 
w typowego więźnia, tak znajomego z filmów amerykańskich [...] pokazano na podtogę i kazano spać położywszy pod głowę spodnie $e^{44}$.

Po powrocie do Krakowa pracował kolejno w Izbie Rolniczej w Krakowie, a następnie Instytucie Rolniczym w Puławach, organizując doświadczalną stadninę koników polskich. W roku 1945 utworzył Dział Hodowli Koni w Państwowym Instytucie Gospodarstwa Wiejskiego w Puławach. Związany był także z Wydziałem Rolniczym Uniwersytetu Marii Curie-Skłodowskiej, gdzie powołał do życia i kierował przez dwa lata Katedrę Ogólnej Hodowli Zwierząt. Jesienią 1947 r. wrócił do pracy na Wydziale Rolniczym UJ, na stanowisko wicedyrektora Instytutu Zootechnicznego. Jednak już w grudniu jego praca zawodowa została przerwana na okres dwóch lat (do 1949) wskutek omyłkowego donosu. Nie załamał się, kontynuował badania, a po powrocie na Uniwersytet pełnił różne funkcje: kierownika Zakładu Mikrobiologii, Katedry Szczegółowej Hodowli Zwierząt, Działu Hodowli Koni Instytutu Zootechniki w Krakowie. Był autorem ponad 200 prac i artykułów naukowych, popularnonaukowych i recenzji, a także członkiem ważnych organizacji naukowych zarówno krajowych, jak i zagranicznych, tj. Royal Socjety of England, członkiem tytularnym PAN, Polskiego Towarzystwa Zootechnicznego ${ }^{45}$.

W dalszej karierze naukowej Romanowi Prawocheńskiemu przeszkodziła choroba. W 1954 r. został sparaliżowany i przez 11 lat zmagał się z chorobą. Zmarł 6 sierpnia 1965 r. w Krakowie.

\section{Jan Licznerski}

Żył w latach 1880-1960. Był prekursorem nowoczesnego mleczarstwa w Polsce, a w głównej mierze serowarstwa. Wiedzę w tym zakresie zdobywał podczas studiów, w krajach słynących z bogatej tradycji serowarskiej, tj. Holandii, Szwajcarii czy Francji, uzyskując przy tym ogromne doświadczenie praktyczne, które przeniósł na grunt polski.

Początkowo pracował jako instruktor mleczarski przy Wydziale Krajowym w Małopolsce. Od 1911 do 1932 r. pełnił funkcję dyrektora Państwowej Szkoły Mleczarskiej w Rzeszowie, która pod nazwą Krajowa Szkoła Mleczarska została oficjalnie otwarta 1 maja w 1903 r. jako pierwsza na ziemiach polskich we wszystkich trzech zaborach. Jej kierownikiem został Tadeusz Rylski, który do dzisiaj jest jej patronem, a szkoła nazywana była i jest „Mleczakiem”. Przetrwała I wojnę światową pod opieką Jana Licznerskiego. W czasie II wojny światowej, sztandar szkoły przechowywał kolejny dyrektor, Jana Cesula (1932-1953), w konwi mleczarskiej zakopanej w swoim ogrodzie. To dzięki tym dwóm dyrektorom Szkoła przetrwała najcięższe okresy historii.

${ }^{44}$ Rękopis autobiografii pisał R. Prawocheński od lat 30. XX w. do osadzenia w obozie koncentracyjnym. Pamiętniki „Na drodze życia” powstały, aby zostawić wiedzę o rodzinie swoim następcom, a także żeby nakreślić obraz sytuacji społ.-polit., gosp. i kulturowy tamtych czasów. Pamiętniki zostały wydane drukiem w 2013 r. w Krakowie.

45 Polski słownik biograficzny, red. Z. Kosiek, Kraków 1948, s. 366. 
Jan Licznerski, od 1932 r., kierował Doświadczalną Serownią w Bażanowicach, w dolinie Bobrówki, w obrębie Pogórza Cieszyńskiego. Jego działalność zmierzała do podniesienia kultury hodowlanej przez właściwe odżywianie krów oraz podniesienia higieny pozyskiwania mleka (jakość i zdatność mleka), a przede wszystkim wprowadzenie bydła zarodowego. Pracował nad metodami wyrobu sera ementalskiego, znanego w Polsce i na świecie. Pracę ułatwiał pierwszy podręcznik serowarski J. Licznerskiego, pt. Serowarstwo (1923), który był traktowany przez znawców przedmiotu jako katechizm mleczarsko-serowarski, służący bez mała trzydzieści lat uczniom szkół średnich, studentom, rzeszy praktyków i pracownikom nauki. Z uwagi na szereg zmian związanych z postępem techniki i nauki serowarstwa, J. Licznerski zdecydował się na wydanie 2 tego podręcznika, pt. Praktyczne serowarstwo (1951), przeznaczonego dla pracowników przemysłu serowarskiego. W przedmowie do książki, prof. dr Eug. Pijanowski napisał:

Do nowego wydania Autor zbierat materiaty w ciagu przeszło dwudziestoletniego okresu dalszej intensywnej pracy doświadczalno-serowarskiej, a samo pisanie pracy miało miejsce w czasie okupacji hitlerowskiej, $w$ bardzo ciężkich warunkach materialnych, w miejscowości Babice pod Rzeszowem. Podeszly wiek $i$ zły stan zdrowia nie przeszkodzity Autorowi w dopięciu od dawna zamierzonego celu.

Jan Licznerski w sposób istotny wpłynął także na powołanie Wydziału Mleczarskiego i Serowarskiego w Wyższej Szkole Rolniczej w Cieszynie, przekształconego w późniejszym okresie w Wydział Technologii Żywności ART w Olsztynie.

\section{Czeslaw Kanafojski}

Był autorem naukowych i praktycznych podstaw nowoczesnej mechanizacji rolnictwa polskiego ${ }^{46}$. Urodził się 22 marca 1898 r. w Kozłówce na Podolu jako syn Stefana, ziemianina, inspektora plantacji buraczanych oraz Józefy z d. Godlewska. Po ukończeniu gimnazjum w Winnicy, rozpoczął w 1917 r. studia mechaniczne w moskiewskiej Wyższej Szkole Technicznej, które przerwał rok później, aby razem z polską armią walczyć w wojnie polsko-bolszewickiej. Po zwolnieniu z wojska, w stopniu podporucznika, podjął studia w zakresie budowy pojazdów na Wydziale Mechanicznym Politechniki Lwowskiej (1922-1927), a następnie studia rolnicze (1929-1931), zdając w krótkim okresie liczne egzaminy z przedmiotów rolniczych. Już w trakcie pierwszych studiów na Politechnice Lwowskiej, powierzono mu obowiązki st. asystenta w Katedrze Maszynoznawstwa Rolniczego w Dublanach k. Lwowa. Jego działalność naukowa i praktyczna miały charakter prekursorski z uwagi na nikłą produkcję maszyn rolniczych w tamtych czasach.

W roku 1934 Cz. Kanafojski został doktorem nauk rolniczych SGGW na podstawie pracy „Przyczynek do laboratoryjnych badań odkształceń i oporów gleby wywołanych działaniem ostróg ciągówki”. Również w tym samym roku został mianowany na stanowisko docenta maszynoznawstwa rolniczego SGGW i Politechniki Lwowskiej. W swojej

46 Stownik biograficzny techników polskich, Warszawa 1999, Stowarzyszeń Naukowo-Technicznych, s. 60-64; Biogramy uczonych polskich, cz. V, Nauki Rolnicze i Leśne, Wyd. PAN 1989, s. 106-109 
pracy czerpał doświadczenia przywiezione z innych krajów, tj. Niemiec, Austrii, Francji, dzięki otrzymanemu państwowemu stypendium naukowemu. Zaangażował się również w tzw. ,akcję siewnikową”, polegającą na powszechnym wprowadzeniu do ówczesnego rozdrobnionego rolnictwa siewników zbożowych. W 1938 r. powierzono mu funkcję kierownika Katedry Maszynoznawstwa Rolniczego Politechniki Lwowskiej, którą de facto kierował w latach 1930-1941.

Po zajęciu Lwowa przez Niemców w 1941 r., koordynował organizację kursów dla traktorzystów w Dublanach, a od marca 1944 w Podzamczu k. Chęcin, nauczając również budowy traktorów i fizyki (Kielce). Po wojnie jako profesor nadzwyczajny (1946) przystąpił do odrodzenia nauki w dziedzinie maszyn rolniczych i organizacji rolnictwa. Zorganizował w SGGW Katedrę Mechanizacji Rolnictwa, którą kierował do 1951 r. Przy tej Katedrze utworzył Stację Doświadczalną Ciągników i Maszyn Rolniczych, przekształconą w 1950 r. w Instytut Mechanizacji i Elektryfikacji Rolnictwa podległy Ministerstwu Rolnictwa. O swoich badaniach pisał w rożnych publikacjach ${ }^{47}$ W SGGW pełnił różne funkcje: dziekana, członka Rady Głównej Szkolnictwa Wyższego, Centralnej Komisji Kwalifikacyjnej, Komitetu Nauk Leśnych PAN. Przyczynił się do również do zorganizowania na Politechnice Warszawskiej nowego kierunku kształcenia, tj. Maszyn i urządzeń rolniczych, a także do utworzenia Wydziału Agromechanicznego, przemianowanego z czasem na Mechanizacji Rolnictwa oraz Wydziału Maszyn i Urządzeń Rolniczych, których był dziekanem.

W 1954 r. uzyskał na Politechnice Warszawskiej drugi doktorat z nauk technicznych i otrzymał tytuł naukowy profesora zwyczajnego. Jego dorobek liczył ponad 100 prac samodzielnych, w tym pięć książek, z których najważniejsza, dwutomowa Teoria i konstrukcja maszyn rolniczych, została przetłumaczona na język angielski, niemiecki i w dużych fragmentach japoński. Będąc członkiem Rady Głównej Szkolnictwa Wyższego, Centralnej Komisji Kwalifikacyjnej, Komitetu Nauk Leśnych PAN itd., angażował się w prace tych organów. Po przejściu na emeryturę podejmował prace w dziedzinie maszyn rolniczych. Odznaczony został m.in. Krzyżem Walecznych, Orderem Sztandaru Pracy II klasy, Krzyżem Oficerskim i Komandorskim Orderu Odrodzenia Polski. Zdaniem Cz. Kanafojskiego, jego największym osiągnięciem było wykształcenie uznanej szkoły naukowej w dziedzinie techniki rolniczej.

Zmarł 5 lutego 1981 r. w Warszawie i spoczął na Cmentarzu Wojskowym na Powązkach. Jego dokonania nie zostały zapomniane. Przyczyniły się do tego w dużej mierze stypendia i nagrody, przyznawane absolwentom uczelni za najlepsze prace dyplomowe w zakresie maszyn rolniczych, a fundowane przez przedsiębiorstwa Agromet i Agromę.

\section{Michal Oczapowski}

Stworzył podstawy polskiego rolnictwa. Urodził się 11 maja 1788 r., w Pociejkach koło Nowogródka, w powiecie słuckim. Był synem proboszcza parafii grekokatolickiej

${ }^{47}$ Cz. Kanafojski, Teoria i konstrukcja maszyn rolniczych, t. 1, cz. 3, Warszawa 1977. 
oraz bratem Jana Chrzciciela (lekarza) i Antoniego (chemika rolnego). Z drugą żoną Michaliną ze Stubielewiczów miał syna Józefa Bohdana, późniejszego wykładowcy na Wydziale Prawa i Administracji Uniwersytetu Jagiellońskiego. Michał Oczapowski żył w czasach, gdy rolnictwo było w katastrofalnym stanie, stąd postawił sobie za cel jego odbudowanie. Interesował się rolnictwem od wczesnej młodości i widział jego zacofanie w porównaniu do krajów zachodnich.

Edukację szkolną, z powodu problemów z oczami, rozpoczął w wieku 15 lat, najpierw w Słucku, a następnie w Nieświeżu. Studia matematyczno-fizyczne odbył w Uniwersytecie Wileński, uzyskując kolejno stopień kandydata (1810), magistra (1811) oraz doktora filozofii na podstawie pracy „Rozprawa o gruntach” (1812). Po ich zakończeniu, przez 8 lat administrował w sposób nowoczesny dobrami w Królestwie Polskim i na Litwie. Prace naukowe na bazie tych doświadczeń drukował w „Dzienniku Wileńskim”. W tym 1819 r. wydał książkę pt. Zasady chemii rolniczej, która była pierwszym w Polsce, a drugim na świecie podręcznikiem nawożenia opartym na badaniach naukowych ${ }^{48}$. Doświadczenie zawodowe zdobywał także podczas podróży naukowych w latach 18191822 po Holandii, Niemczech, Francji i Anglii, część trasy pokonując pieszo. W Niemczech odbył studia u prof. A. Thaera w Mőgiln, od którego przejął teorię rolnictwa i prawdopodobnie teorię próchniczno-fizjologiczną.

Po powrocie z podróży naukowej w 1822 r., jako profesor rolnictwa, objął Katedrę Gospodarstwa Wiejskiego na Uniwersytecie Wileńskim. Oprócz wykładów M. Oczapowski prowadził doświadczenia rolnicze w majątkach uniwersyteckich. Jego prace naukowo-badawcze miały dwojaki charakter, z jednej strony wyznaczały podstawowe założenia dla praktycznego rolnictwa w przyszłości, z drugiej, bliższej Oczapowskiemu, miały za zadanie podniesienie rolnictwa w bieżącej dobie, a co za tym idzie szybkiego podniesienia warunków życia. Realizację programu, jaki sobie zakreślił, oparł na oświacie rolniczej dla różnego poziomu odbiorców.

Po zamknięciu w 1832 r. Uniwersytetu Wileńskiego przez cara Mikołaj I, Michał Oczapowski pełnił obowiązki wizytatora i członka Komitetu Cenzury. Po otrzymaniu emerytury przeniósł się do Królestwa, gdzie w 1833 r. powierzono mu kierownictwo Instytutu Gospodarstwa Wiejskiego i Leśnictwa w Marymoncie. W tym czasie powstaje jego 16 tomowe dzieło Gospodarstwo Wiejskie, stanowiące podstawy naukowe właściwego rolnictwa i jego pochodnych. Powiązał ze sobą poszczególne gałęzie rolnictwa i podkreślił wartość praktyczną tej całości. Dzieło kierował nie tylko do ludzi nauki, ale przede wszystkim do praktyków i swoich studentów. Świadczy o tym zamieszczony podtytuł Teoretyczno-praktycznie wyłożone. M. Oczapowski upowszechniał wiedzę we własnym narodzie ucząc, jak należy prowadzić gospodarstwo rolne oparte na podstawach naukowych. Tak pisał o nim jeden z jego uczniów: postawił dla siebie pomnik $w 7$ znanych powszechnie dziełach swych gospodarskich $i$ właśnie z owego pomnika osobliwie

${ }^{48}$ M. Koter, Michat Oczapowski jako twórca chemii organicznej w Polsce, „Roczniki Gleboznawcze” 1971, t. XXII, z. 2. 
też dla tego, który szczyci się, że byt jego uczniem (Majewski), najwłaściwiej może być $w$ dziejowym rozwoju ziemiaństwa polskiego oceniony.

Ustąpienie prof. Michała Oczapowskiego z Marymontu nastąpiło 11 listopada $1853 \mathrm{r}$. w niejasnych okolicznościach. Zmarł dwa miesiące później, 9 stycznia 1854 r. w Warszawie i został pochowany na Cmentarzu Wawrzyszewskim. Żona wraz z małoletnim synem ufundowali pamiątkową tablicę w jego kościele parafialnym. Po śmierci nie zapomniano o nim. Od 1962 r. jest patronem jednej z ulic na Bielanach w Warszawie, od 1989 r. był patronem Akademii Rolniczo-Technicznej w Olsztynie, Centralna Biblioteka Rolnicza w Warszawie nosi jego imię. Medal im. Michała Oczapowskiego, od 1988 r., wręcza się wybitnym naukowcom z dziedziny nauk rolniczych.

Przedstawione powyżej historie ulic i ich patronów są tylko początkiem badania miejsc pamięci związanych z Uniwersytetem Warmińsko-Mazurskim w Olsztynie. Dla mnie place i ulice zaczęły „mówić”, ale jeszcze bardziej fascynujące okazały się dokonania patriotyczne, społeczne i zawodowe ich patronów.

\section{Bibliografia}

\section{Źródła}

Archiwum i Muzeum UWM, Biuro Rektora ART w Olsztynie, Nadawanie nazw ulicom w Kortowie, sygn. 2240/35, Decyzja nr 5 w sprawie powołania Komisji ds. rozstrzygnięcia konkursu na nadanie nazw ulic w Kortowie, 28.04. 1986.

AM UWM, Biuro Rektora ART w Olsztynie, Nadawanie nazw ulicom w Kortowie, sygn. 2240/35, Protokół z posiedzenia komisji ds. rozstrzygnięcia o nadanie nazw ulic w Kortowie, 6 czerwca $1986 \mathrm{r}$

AM UWM, Biuro Rektora ART. w Olsztynie. Nadawanie nazw ulicom w Kortowie, sygn. 2240/35. Pismo Katedry Ogólnej Uprawy Roślin ART. w Olsztynie do Rektora Włodzimierza Barana w sprawie nazwy jednej z głównych arterii w Kortowie. 1987.

AM UWM, Biuro Rektora ART. w Olsztynie. Nadawanie nazw ulicom w Kortowie, sygn. 2240/35. Pismo Wydziału Zootechniki Ochrony do dyrektora Administracyjnego ART. mgr Edmunda Nazdrowicza, w sprawie nazwania zaznaczonej na planie ulicy im. Romana Prawocheńskiego. 11.11.1987.

AM UWM, Biuro Rektora ART. w Olsztynie. Nadawanie nazw ulicom w Kortowie, sygn. 2240/35. Pismo od Dziekana Wydziału Technologii Żywności prof. dr hab. Stefana Smoczyńskiego do dyrektora Administracyjnego ART. mgr Edmunda Nazdrowicza, w sprawie nazwania ulicy, od bloku 23/24 do bloku 11/37, im. Jana Licznerskiego, 23.11.1987.

AM UWM, Biuro Rektora ART. w Olsztynie. Nadawanie nazw ulicom w Kortowie, sygn. 2240/35. Pismo od Dziekan prof. dr hab. Remigiusz Fiiko, do dyrektora Administracyjnego ART. mgr Edmunda Nazdrowicza, w sprawie nazwania ulicy biegnącej od trasy autobusu linii nr 3 do CPN imieniem dr Kurta Obitza, 21.07.1987.

AM UWM, Biuro Rektora ART. w Olsztynie. Nadawanie nazw ulicom w Kortowie, sygn. 2240/35, Pismo do dyrektora Administracyjnego ART. mgr Edmunda Nazdrowicza, do dziekana Wy- 
działu Ochrony Wód i Rybactwa Śródlądowego, doc. dr hab. Konstanty Lossow w sprawie nazwania ulicy imieniem Benedykta Dybowskiego. 20.11.1987 r.

AM UWM, Biuro Rektora ART. w Olsztynie. Nadawanie nazw ulicom w Kortowie, sygn. 2240/35. Pismo dziekana Wydziału Mechanicznego, doc. dr hab. Kazimierza Wierzbickigo do dyrektora Administracyjnego ART mgr Edmunda Nazdrowicza, z propozycją nazwania wyznaczonej ulicy im. prof. zw. dr. hab. inż. Czesława Kanafojskiego, a także z propozycją nazwania jednej z ulic przy Wydziale Mechanicznym ulicą Techniczną a drugą ulicą Rolniczą. 11.10.1987.

AM UWM, Biuro Rektora ART. w Olsztynie. Nadawanie nazw ulicom w Kortowie, sygn. 2240/35, Pismo Witolda Niewiadomskiego i Michała Skrodzkiego z Katedry Ogólnej Uprawy Roli i Roślin Wydziału Rolniczego ART w sprawie nazwania jednej z ulic w Kortowie, im. prof. Bolesława Świętochowskiego.

AM UWM, Biuro Rektora ART. w Olsztynie. Nadawanie nazw ulicom w Kortowie, sygn. 2240/35. Wniosek do Przewodniczącego Miejskiej Rady Narodowej w Olsztynie, ob. inż. Stanisława Grzegorzaka o nadanie nazw ulicom Kortowa. 15.03.1988.

AM UWM, Biuro Rektora ART. w Olsztynie. Korespondencja wewnętrzna i zewnętrzna 19871988. Pismo sekretarza uczelni z Biura Rektora, mgr inż. Ewy Burskiej-Kazimierskiej do przewodniczącego Rady Osiedla „Kortowo”, obywatela dr Zbigniewa Wróbla w sprawie zaopiniowania wniosku, 08.12.1987.

AM UWM, Biuro Rektora ART. w Olsztynie. Nadawanie nazw ulicom w Kortowie, sygn. 2240/35. Pismo od przewodniczącego Rady Osiedla obywatela dr Zbigniewa Wróbla do Dyrektora Administracyjnego ART. w Olsztynie, 09.03.1988.

Archiwum Państwowe w Olsztynie, Miejska Rada Narodowa, sygn. 1278, Protokół NIII/88, s. 1. Opinia Komisji Kultury, Kultury Fizycznej i Turystyki MRN dla Komisji Oświaty i Wychowania MRN dotycząca projektu uchwały w sprawie nazewnictwa ulic w mieście.

APO, Miejska Rada Narodowa, sygn. 1278, Protokół NIII/88, Uzasadnienie do uchwały Miejskiej Rady Narodowej w Olsztynie w sprawie nadania nazw ulicom i placom na terenie miasta Olsztyna.

APO, Miejska Rada Narodowa, sygn. 1278, W sprawie nadania nazw ulicom i placom na terenie miasta Olsztyna. Załącznik nr 15 oraz Załącznik nr 17.

AM UWM, Biuro Rektora ART w Olsztynie, Nadawanie nazw ulicom w Kortowie, sygn. 2240/35, Pismo z-cy dyrektora administracyjnego d/s technicznych, inż. Stanisława Kurjana do kierowników jednostek Organizacyjnych w/m. 23.03.1989.

Archiwum Państwowe w Olsztynie, Miejska Rada Narodowa, sygn. 1278, Protokół NIII/88, s. 1. Opinia Komisji Kultury, Kultury Fizycznej i Turystyki MRN dla Komisji Oświaty i Wychowania MRN dotycząca projektu uchwały w sprawie nazewnictwa ulic w mieście.

APO, Miejska Rada Narodowa, sygn. 1278, Protokół NIII/88, Uzasadnienie do uchwały Miejskiej Rady Narodowej w Olsztynie w sprawie nadania nazw ulicom i placom na terenie miasta Olsztyna.

APO, Miejska Rada Narodowa, sygn. 1278, W sprawie nadania nazw ulicom i placom na terenie miasta Olsztyna. Załącznik nr 15 oraz Załącznik nr 17.

AM UWM, Biuro Rektora ART w Olsztynie, Nadawanie nazw ulicom w Kortowie, sygn. 2240/35, Pismo z-cy dyrektora administracyjnego d/s technicznych, inż. Stanisława Kurjana do kierowników jednostek Organizacyjnych w/m. 23.03.1989. 


\section{Literatura}

Achremczyk S., Kortowo - od folwarku do uniwersyteckiego miasteczka, w: J.M. Garbula (red.), Mikrohistoria Kortowa. Konteksty - Refleksje - Narracje, Olsztyn 2014.

Biogramy uczonych polskich, cz. V, „Nauki Rolnicze i Leśne” 1989.

Bykowski L., Dybowski Benedykt, w: W. Konopczyński (red. gł.), Polski słownik biograficzny, t. VI, Kraków 1948.

Chłosta J., Trzy osobliwe tajemnice dawnego Kortowa, w: J.M. Garbula (red.), Mikrohistoria Kortowa. Konteksty - Refleksje - Narracje, Olsztyn 2014.

Delaperrière M., Miejsca pamięci czy pamięć miejsc? Kilka refleksji na temat uobecniania przeszłości w literaturze współczesnej, „Ruch Literacki” 2013, R. LIV, z. 1 (316).

Dyakowski B., Badacz Dalekiej Pótnocy. Benedykt Dybowski, Poznań - Warszawa - Wilno - Lublin 1931.

Dziekońska-Rynko J., Mierzwa-Szymkowiak D., Słupek M., Benedykt Dybowski (1833-1930) lekarz, przyrodnik, społecznik, patriota. Wydarzenia upamiętniajace polskie badania na Syberii i Kamczatce, Biuletyn „PANorama” 2018, nr 4 (6).

Dybowski B., O Syberyi i Kamczatce, Lwów 1899.

Kanafojski Cz., Teoria i konstrukcja maszyn rolniczych, t. 1, cz. 3, Warszawa 1977.

Koter M., Michał Oczapowski jako twórca chemii organicznej w Polsce, „Roczniki Gleboznawcze” 1971, t. XXII, z. 2.

Mikrohistoria Kortowa. Konteksty-Refleksje-Narracje, J.M. Garbula (red.), Olsztyn 2014.

Obitz K,, Młodzież Mazurska!, „Cech” 1931, nr 4.

Polski słownik biograficzny, Z. Kosiek (red.), Kraków 1948.

Prawocheński R., W sprawie ochrony konia w Polsce, „Gazeta Rolnicza” 1935, nr 33/34.

Prawocheński R., Listy z Anglii, „Gazeta Rolnicza” 1935, nr 33/34.

Prawocheński R., Wrażenia z IPA, „Gazeta Rolnicza” 1930, nr 27/28.

Prawocheński R., Na drodze życia, Kraków 2013.

Stownik biograficzny techników polskich, Warszawa 1999, Stowarzyszeń Naukowo-Technicznych.

Staliński Z., Złota księga Akademii Rolniczej im. Hugona Kottątaja, Kraków 2003.

Szpociński A., Nośniki pamięci, miejsca pamięci, „Sensus Historiae” 2014, vol. XVII.

Wadowski S., Wspomnienia o doktorze Obitzu, „Warmia i Mazury” 1962, nr 1.

Wańkowicz M., Na tropach Smętka, Warszawa 1958.

Waszkiewicz T., Obitz Kurt Albert (1907-1945), Polski stownik biograficzny, t. XXIII, Wrocław Warszawa - Kraków - Gdańsk 1978. 